\title{
Turbidity measurements as a tool of monitoring and control of the SBR effluent at the small wastewater treatment plant - preliminary study
}

\author{
Zbigniew Mucha*, Przemysław Kułakowski \\ Cracow University of Technology, Poland \\ Institute of Water Supply and Environmental Protection \\ Department of Environmental Technology \\ *Corresponding author's e-mail: zmucha1@interia.pl
}

Keywords: effluent quality, wastewater turbidity, SBR reactor, TSS, COD, wastewater treatment plant control.

\begin{abstract}
The paper presents preliminary results of investigations on a relationship between turbidity and other quality parameters in the SBR plant effluent. The laboratory tests demonstrated a high correlation between an effluent turbidity and a total suspended solids (TSS) concentration as well as between TSS and COD. Such a relationship would help to continuously monitor and control quality of a wastewater discharge using turbidity measurement.
\end{abstract}

\section{Introduction}

Total suspended solids (TSS), $\mathrm{BOD}_{5}$ and COD are the principal parameters of wastewater effluent monitoring. They are standardized and if performed in the certified laboratories, they may be used to evaluate treatment plant efficiency and its compliance with the actual discharge requirements. However, their actual importance for the plant operator may be sometimes limited because of a comparatively long time between sampling and actual results. This time may vary from a few hours (TSS or COD) to 5 days in the case of $\mathrm{BOD}_{5}$. Therefore, alternate indicators measured in real-time, even if not standardized and certified, may help operators during a decision making process. A turbidity measurement seems especially interesting as such indicator.

Water turbidity is caused by the presence of suspended particles of a different diameter, ranging from very small colloidal particles to large flocs, which scatter and absorb electromagnetic radiation in IR and VIS ranges. Particles may be both of mineral and organic origin in surface waters, however organic suspended matter is usually observed in a wastewater treatment plant effluent.

Different units are used to express turbidity measurement. FNU (Formazin Nephelometric Unit) is usually used in wastewater turbidity measurements, whileNTU(Nephelometric Turbidity Unit) is used for water turbidity. As it has been stated, FNU is equal to NTU, however there is a difference in the way FNU and NTU are measured [Oregon Water 2014]. Sometimes also FAU (Formazin Attenuation Unit) is used.

Wastewater analyses presented in this paper allowed to establish the relationship between turbidity and TSS concentrations in the SBR effluent. Also the relationship of turbidity versus COD was tested.
There is hardly any information on this topic in the published papers. In Germany, Koch and Schlesinger (Koch et al. 2003) have investigated the correlation between turbidity and TSS concentrations in the effluent from small wastewater treatment plants. Use of turbidity measurements for controlling small wastewater treatment plant operation was also described by Dargeloh (Dargeloh 2007). More often a relationship between turbidity and TSS concentrations in surface inland or coastal waters is discussed (Chanson et al. 2008, Pavanelli et al. 2009, Slaets et al. 2014). A growing interest in such relationships in the treatment plant effluent may be expected, because newly-built plants start to employ probes for continuous turbidity measurement (Duclos et al. 2013).

\section{Wastewater treatment plant characteristics}

The wastewater treatment plant employs the Sequencing Batch Reactor (SBR) technology. According to the project, the construction of the plant has been planned as a two - stage project. After the first stage, the plant capacity, expressed as a flow rate and PE (People Equivalent) can achieve $720 \mathrm{~m}^{3} \cdot \mathrm{d}^{-1}$ and 7,300, respectively. The raw wastewater composition is typical for high concentrated municipal wastewater with an increased content of nitrogen and phosphorus caused by a significant portion of wastewater transported from septic tanks. During the investigations, the average wastewater flow was $250 \mathrm{~m}^{3} \cdot \mathrm{d}^{-1}$.

The mechanical treatment comprised a fine vertical sieve of $3 \mathrm{~mm}$ opening and an aerated horizontal grit chamber for sedimentation of suspended matter. After preliminary mechanical treatment wastewater was collected in a retention tank. Then, biological treatment followed using activated sludge SBR technology in two treatment lines. SBR reactors 
have been made of stainless steel and equipped with aeratingmixing devices, additionally supported with blowers. Chemical precipitation of phosphorus may be carried out by the addition of iron sulfate (PIX) to the reactors. There was no necessity of phosphorus precipitation during research. A floating decanter with a diameter of $150 \mathrm{~mm}$ removed secondary effluent from the reactor of $650 \mathrm{~m}^{3}$ capacity. The first wave of the effluent (first-flush) carrying out activated sludge flocs was directed to a wastewater retention tank. The time of the first-flush was pre-set during the plant start-up and could be revised later by adjustment of the automatic valve opening time.

The wastewater treatment plant uses aerobic sludge digestion for sludge treatment. The process proceeds in a separate tank and is followed by dewatering of digested sludge in a centrifuge. The plant layout is shown in Fig. 1.

\section{Methods}

The research works were carried out to establish the relationship between on-line measurements of effluent turbidity and other wastewater quality parameters. Such a relationship may be used to control the SBR decanter operation, especially during the first-flush phase. Investigations were carried out in July and August 2013 during a routine operation of the wastewater treatment plant, at the actual hydraulic and pollutant loadings, which were lower than the designed ones. During the investigations wastewater quality and activated sludge parameters were measured as well as the effluent flow rates. During a sampling procedure wastewater turbidity was readout from the turbidity meter, installed in the $200 \mathrm{~mm}$ diameter pipe located at the reactor outlet.

The following equipment was used to measure wastewater flows and turbidity:

- Endress+Hauser electromagnetic flowmeter connected to recorder,

- Endress+Hauser nephelometric turbidimeter equipped with a four beam optical turbidity sensor Turbimax CUS51D of the $860 \pm 30 \mathrm{~nm}$ light wave.

Wastewater samples were taken manually in day hours. The sampling frequency varied according to turbidity changes to obtain a wide spectrum of results. The analysis shown in Table 1 was done by the certified laboratory while the other samples were analyzed in the laboratory of the Department of Environmental Technologies, Cracow University of Technology. Total suspended solids and COD concentrations were conducted according to the Polish Standards. Three series of samples were analyzed.

Raw wastewater and the effluent quality parameters as well as treatment process parameters are shown in Tables 1 and 2. High values of total phosphorus and total nitrogen

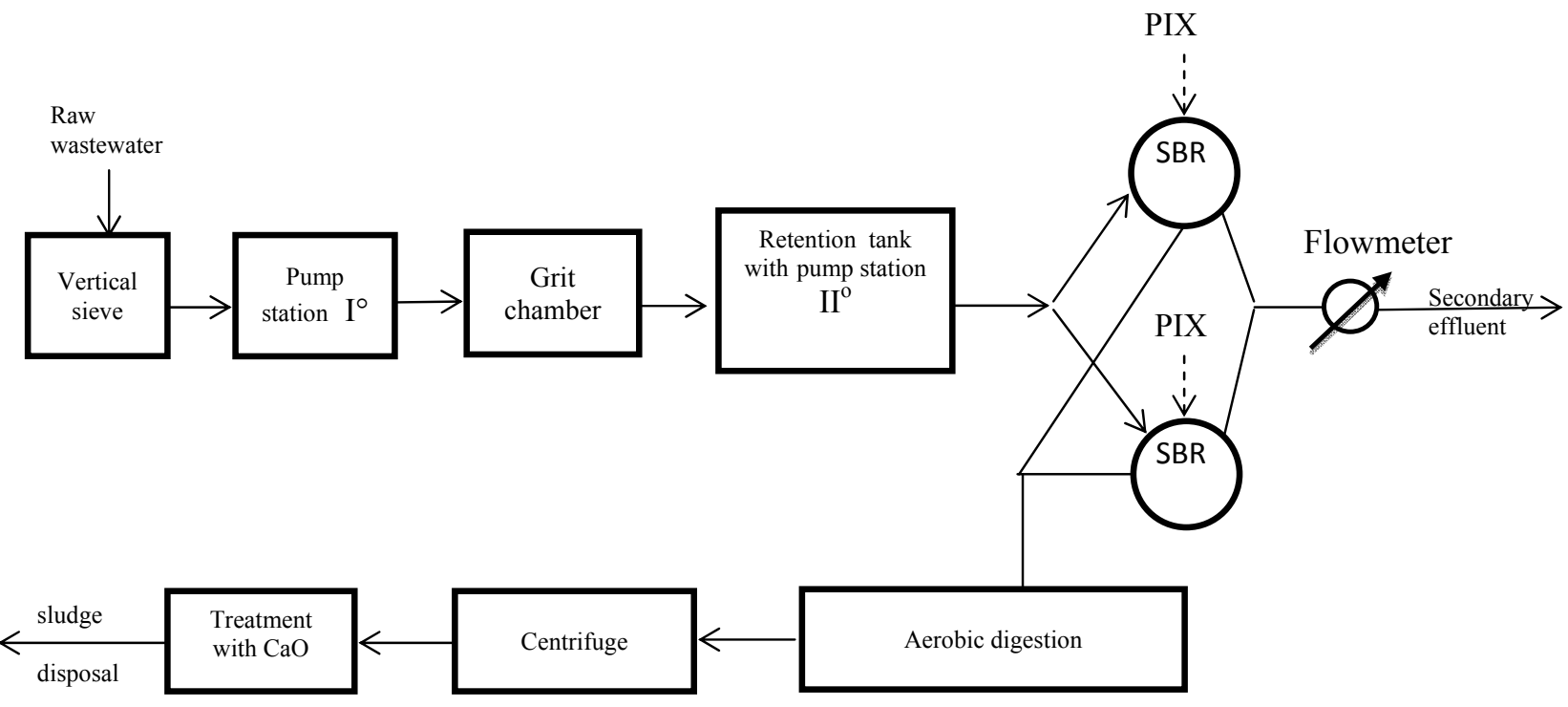

Fig. 1. Flow-scheme of the wastewater treatment plant

Table 1. Design and actual values of parameters in raw wastewater and the effluent (data for 17 samples)

\begin{tabular}{|l|c|c|c|c|}
\hline \multirow{2}{*}{\multicolumn{1}{|c|}{ Parameter }} & \multicolumn{2}{c|}{ Raw wastewater } & \multicolumn{2}{c|}{ Effluent } \\
\cline { 2 - 5 } & Actual value & Design value & Actual value & Permit value \\
\hline Wastewater flow, $\mathrm{m}^{3} / \mathrm{d}$ & 250 & 720 & 250 & 720 \\
\hline $\mathrm{BOD}_{5} . \mathrm{gO}_{2} / \mathrm{m}^{3}$ & 1276 & 608 & $2,6-8,0$ & 25 \\
\hline $\mathrm{COD}, \mathrm{gO}_{2} / \mathrm{m}^{3}$ & 3610 & 1216 & $33-59$ & 125 \\
\hline Total suspended solids, $\mathrm{g} / \mathrm{m}^{3}$ & 1397 & 608 & $5,4-8,8$ & 35 \\
\hline Total nitrogen, $\mathrm{gN} / \mathrm{m}^{3}$ & 296 & 111 & $1,4-42,3$ & $35 \%$ removal \\
\hline Total phosphorus, $\mathrm{gP} / \mathrm{m}^{3}$ & 49 & 20 & $0,7-15,3$ & $40 \%$ removal \\
\hline
\end{tabular}


can be observed. They originate from a significant share of wastewater transported to the plant from septic tanks.

\section{Results and discussion}

During the studies 57 effluent samples were taken and TSS concentrations were determined in each sample. Moreover, COD was measured in 19 samples as well. During the sampling procedure a turbidity value was read out from the on-line turbidity meter. The dependence between the TSS and turbidity values is shown in Figure 2.

The minimum chi-square method was used to describe the linear regression shown in Fig. 2:

TSS $\left(\mathrm{mg} \cdot \mathrm{dm}^{-3}\right)=1.61 *$ turbidity $(\mathrm{FNU})-0.93$.
The correlation strength coefficient $r$ is 0.977 so it is significantly higher than the critical value $r_{c r}=0.221$. The values show the strong correlation between a total suspended solids concentration and turbidity in the effluent from the treatment plant.

Total suspended solids concentration vs. COD dependence is presented in Fig. 3.

Also in this case a linear regression between these two parameters can be observed:

$$
\mathrm{COD}\left(\mathrm{mgO}_{2} \cdot \mathrm{dm}^{-3}\right)=2.06 \cdot \text { turbidity }(\mathrm{FNU})+37.2
$$

The calculated correlation strength coefficient $\mathrm{r}$ was 0.860 and it was significantly higher than the critical value,

Table 2. Design and actual values of process parameters at the WWTP

\begin{tabular}{|l|c|c|}
\hline \multirow{2}{*}{ Process parameter } & \multicolumn{2}{c|}{ Value } \\
\cline { 2 - 3 } & Actual & Design \\
\hline F/M ratio, $\mathrm{g} \mathrm{BOD} / \mathrm{g}^{*} \mathrm{~d}$ & 0,07 & 0,1 \\
\hline Sludge age, $\mathrm{d}$ & 19 & 6 \\
\hline Cycle time, $\mathrm{h}$ & 8 & $6,5-5$ \\
\hline Sludge concentration, $\mathrm{kg} / \mathrm{m}^{3}$ & $4-8$ & 13 \\
\hline Sludge index, $\mathrm{ml} / \mathrm{dm}^{3}$ & $50-80$ & 100 \\
\hline
\end{tabular}

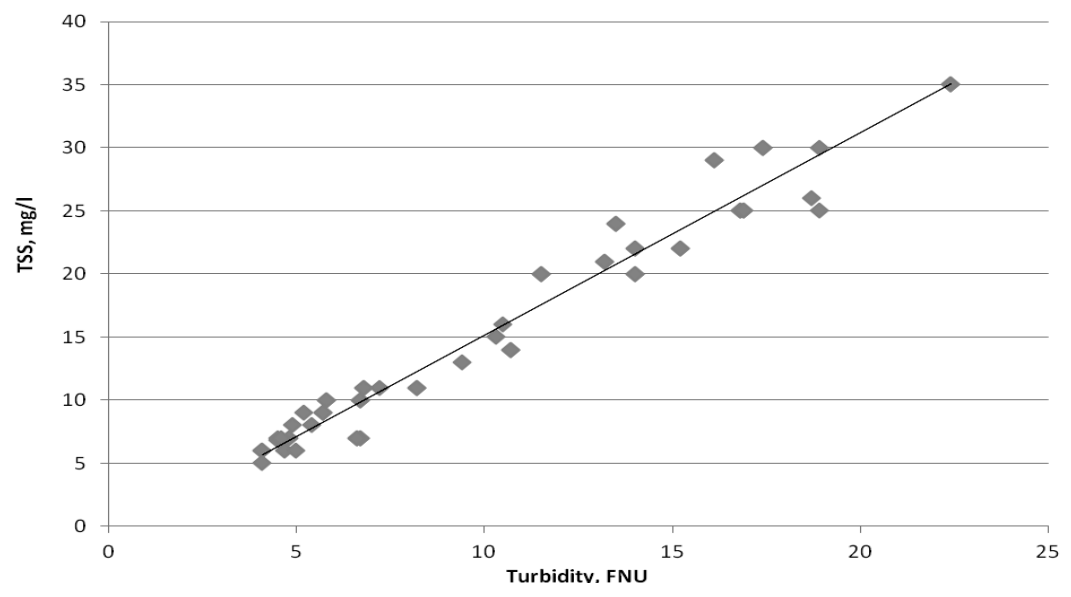

Fig. 2. Total suspended solids concentration vs turbidity in the effluent

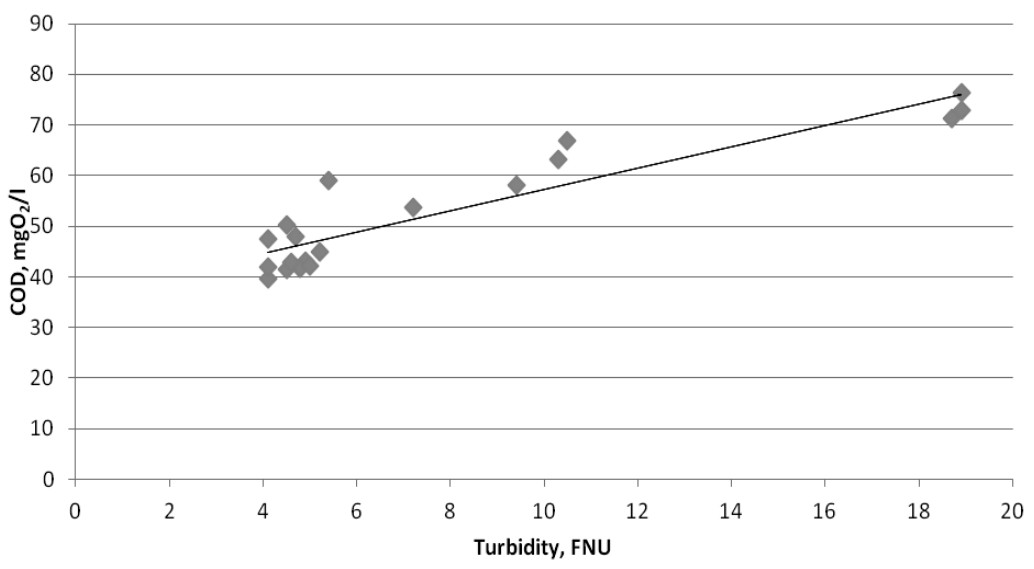

Fig. 3. COD concentration vs. turbidity in the effluent 
so a hypothesis on a linear correlation between TSS and COD cannot be discarded.

The line intersects the Y-axis above 0 in Fig. 3. This shift may be caused by the method of COD determination; only non-filtered samples were determined, so the COD measurements are the sum of a non-dissolved phase and a dissolved phase, which is not measured as turbidity.

\section{Summary}

New devices used for continuous measurement of wastewater turbidity provide an interesting opportunity to use their results for wastewater treatment process monitoring and control. In this particular case, turbidity measurements were not originally expected to be used in process monitoring and control, they were planned for general monitoring of wastewater quality only.

The investigations enable preparation of a proper controller program and use the effluent turbidity value to control the discharge of the first-flush wave. Up to now the effluent discharge was carried out according to a gate valve opening time, fixed for the reactor cycle.

The investigation was carried out in small wastewater plant and during summer period only, so the results presented in this paper cannot be generalized for all WWTP.

It should be also interesting to continue the investigations at the continuous-flow wastewater treatment plants. The preliminary results obtained by the authors at such plants differed slightly from those presented in this paper.

\section{References}

Chanson, H., Takeuchi, M. \& Trevethan, M. (2008). Using turbidity and acoustic backscatter intensity as surrogate measures of suspended sediment concentration in a small subtropical estuary, Journal of Environmental Management, 88, pp. 1406-1416.

Dargeloh, E. (2007). Use of turbidity measurement for determination of small wastewater treatment plants disinfection efficiency, RWTH Aachen 2007. (in German)

Duclos, N., Molle, P., Laurent, J., Wanko, A. \& Mosé, R. (2013). Constructed wetlands to treat micropollutants of urban runoff from three residential watersheds, $8^{\text {th }}$ International Conference NOVATECH, Lyon 2013.

Koch, M. \& Schlesinger, R. (2003). Decentralised wastewater treatment plants - new achievements, sanitary aspect, Lauta 2003. (in German)

Oregon Water Science Center (http://or.water.usgs.gov/grapher/fnu. html (11.03.2014)).

Pavanelli, D. \& Bigi, A. (2009). Indirect methods to estimate suspended sediment concentration: reliability and relationship of turbidity and settleable solids, Water Research, 43, pp. 2179-2190.

Slaets, J.I.F., Schmitter, P., Hilger, T.. Lamers, M., Piepho, H-P., Duc Vien, T. \& Cadish, G. (2014). A turbidity-based method to continuously monitor sediment, carbon and nitrogen flows in mountainous watersheds, Journal of Hydrology, 513, pp. 45-57.

\section{Wstępne badania nad zastosowaniem pomiaru mętności ścieków oczyszczonych jako elementu kontroli i sterowania pracą oczyszczalni o działaniu cyklicznym}

\footnotetext{
Streszczenie: W artykule przedstawiono wstępne wyniki badań zależności pomiędzy mętnością a innymi wskaźnikami zanieczyszczeń w ściekach oczyszczonych odpływających z oczyszczalni z reaktorami osadu czynnego o działaniu cyklicznym typu SBR. Wykonane badania potwierdzają wysoką korelację zarówno pomiędzy wartością mętności a stężeniem zawiesiny jak i pomiędzy wartością mętności a ChZT w ściekach oczyszczonych co może pozwolić na ciągłą kontrolę i sterowanie jakością ścieków odpływających do odbiornika przy zastosowaniu pomiaru mętności.
} 